\title{
A Revolução de Outubro e o problema das nacionalidades
}

\author{
RONALD G. SUNY
}

$\mathrm{D}$ ESDE PELO MENOS o momento da conquista de Kazan por Ivan IV, tem havido peculiar conexão entre as formas de poder estatal na Rússia e a freqüentemente descartada questão nacional. Quando, em meados do século XV, a Rússia deixou de ser uma nação relativamente homogênea etnicamente, tornando-se uma nação multinacional, as relações entre a elite governante - constituída amplamente por étnicos russos e não-russos russificados e os povos nãorussos subordinados, referidos variavelmente como inorodtsy ou inozemtsy-foram sempre desiguais, de subordinação e superordenação, nas quais aqueles com competência cultural russa tinham acesso privilegiado ao poder e prestígio. Embora o acesso à elite nunca estivesse inteiramente fechado para os não-russos, o grau de dificuldade para o movimento social ascendente diferia entre os povos não-russos. Enquanto os alemães bálticos tinham entrada relativamente fácil aos círculos de poder, outros povos, notadamente os judeus, os muçulmanos da Ásia Central, e os armênios após 1885, encontravam seu caminho bloqueado. As práticas czaristas - que distinguiam a comunidade central étnico-religiosa, os russos, dos outros e, ao mesmo tempo, mantinham estes outros periféricos em uma relação subordinada à nacionalidade central - podem ser caracterizadas como imperiais.

\section{A Rússia imperial}

Embora uma protoautocracia tenha existido em Muscovy antes de Ivan IV, a longevidade da autocracia e as racionalizações ideológicas que a acompanharam estavam vinculadas ao imperativo político de manutenção da unidade do Estado e da estrutura hierárquica social e racial face à heterogeneidade étnica do império russo. Enquanto os povos eram entendidos como sendo cultural e etnicamente superiores e inferiores, a multinacionalidade, em um contexto de relações interétnicas desiguais e de exploração, constituía um impedimento estrutural-chave para o desenvolvimento de formas políticas alternativas. A manutenção conservadora de relações basicamente desiguais, imperiais, entre os povos tornava difícil a introdução às formas constitucionais mais liberais e utópicas, às reformas democráticas. Embora alguns líderes políticos russos tenham reconhecido, ainda que relutantemente, que manter o império impedia a probabilidade de um sistema político representativo, outros, dos liberais aos bolcheviques, tentaram forçar uma união entre o Estado unitário que o czarismo havia criado e alguma forma de política democrática.

A variedade de entidades políticas no interior do império russo, desde o grão-ducado da Finlândia e o vice-reinado da Caucásia até o canato de Bukhara e 
Khiva, eram lembranças indeléveis dos estágios da expansão que continuou até os últimos dias do domínio dos Romanov. Mantido unido pela força militar e pela idéia de lealdade ao czar, o império russo não foi concebido em termos étnicos (russkaia imperiia), mas como uma coleção cosmopolita de povos e nações (rossiskaia imperiia) sob um soberano único. A elite dirigente era igualmente cosmopolita, com certeza russofone, mas constituída de membros de várias nacionalidades - poloneses, alemães, georgianos e tártaros assimilados, entre outros - os quais, uma vez tendo se tornado servidores leais do imperador, perderam muito de sua identificação com os povos de onde se originavam. As elites políticas eram cooptadas ao serviço imperial e, por muito dos séculos XVIII e XIX, a política russa foi extraordinariamente vitoriosa em desenraizar aqueles que poderiam ter sido os líderes da resistência ao domínio do Estado central.

Os povos não-russos eram governados em um sistema contraditório que envolvia domínio indireto em alguns lugares, governo militar direto através das elites locais assimiladas ao sistema administrativo russo em outros, e várias formas de constitucionalismo (no grão-ducado da Finlândia e, até 1863, no reino da Polônia). Entre os efeitos do czarismo estavam a imposição de uma nova ordem estatal em sociedades que tinham pouco contato com fortes estruturas estatais, novos regulamentos e leis, a difusão da servidão a certas regiões, como a Georgia, e a compulsoriedade de nova taxação. Essa russificação administrativa - a extensão do absolutismo burocrático sobre sujeitos não-russos - foi acompanhada por uma auto-russificação espontânea, que muitos não-russos consideraram vantajosa nos dois primeiros terços do século XIX. Mas após 1881, quando o governo adotou um conjunto de políticas mais estridentemente antinacionais e anti-semitas que ameaçavam uma homogeneização cultural forçada, etnias como a dos armênios, que tinham sido russófilas, tornaram-se hostis ao regime czarista.

\section{Fevereiro e os povos não-russos}

A Revolução de Fevereiro foi marcada por extraordinária confiança no poder de soluções jurídicas para melhorar os profundos conflitos sociais e étnicos. Os males que haviam conduzido a hostilidades de classe e nacionais foram atribuídos ao czarismo e se defendia a idéia de que uma legislação apropriada, na direção liberal ocidental, removeria os obstáculos às soluções. Em um de seus primeiros atos (em 8 de março), o governo provisório restaurou a constituição do grãoducado da Finlândia. O manifesto enfatizava a ilegalidade dos regulamentos czaristas que contraditavam com as leis da Finlândia. Quatro dias mais tarde, os jornais anunciavam que o governo pretendia abolir todas as restrições legais baseadas em religião, nacionalidade e classe [aqui referida primeiramente como estamento (soslovie) e posto (chin)]. Quando o primeiro ministro Lvov assinou a lei (em $20 \mathrm{de}$ março), foi saudado por um editorial no conservador Novoe Vremia, que expressou tanto o medo que "as forças centrífugas em desenvolvimento e as aspirações separatistas das nacionalidades que compõem a Rússia" representassem um "perigo real de decomposição gradual do Estado em suas partes componentes”, quanto 
a esperança de que "agora todos os obstáculos ao mútuo entendimento entre os povos da Rússia tinham sucumbido à luz da liberdade que rompe sobre o país". Tal otimismo de que "a liberdade unirá" demonstrou a fé nas soluções jurídicas mas também preparou o terreno para amargo desapontamento quando os problemas associados com as nacionalidades provou ser bem mais intratável do que imaginado.

Ao final de março, quando o governo elaborou suas provisões para o autogoverno local, o princípio da nacionalidade foi levado em consideração de duas formas. $\mathrm{Na}$ formação das províncias de Estland e Lifland, as fronteiras naturais entre elas deveriam ser delimitadas de acordo com a etnia. Mas, estendendo as zemstva (1) à Sibéria e à província de Arkhangel'sk, o governo isentou as áreas ocupadas por samoeds nômades, vários outros inorodsy e cossacos, para os quais instituições e regulamentos especiais deveriam ser implementados. Leis específicas foram editadas para o Turquestão (onde as autoridades locais deveriam decidir se as zemstva eram apropriadas para vários distritos e povos), para as estepes de Kalmyk e terras da horda interna da Quirguizia. Planos para estender as zemstva à Transcaucásia e às regiões cossacas do Sul da Rússia ainda estavam sendo formuladas quando o governo provisório foi derrubado. A nacionalidade foi claramente considerada na formulação da política, mas o governo e os principais partidos políticos com influência sobre ele estavam muito mais preocupados com a unidade do Estado em tempos de grande perigo. Ao invés de aceitar as implicações radicais do princípio da autodeterminação nacional, os políticos liberais e conservadores mantiveram uma atitute paternalística com relação à maioria dos povos não-russos. $\mathrm{E}$ os socialistas moderados desejavam acompanhar a consistente postergação de duras decisões pelo governo, até a reunião da Assembléia Constituinte.

Os cadetes, que formavam o partido liberal líder, opuseram-se à autonomia política territorial nacional, a uma estrutura federal para a nova Rússia e a qualquer forma de separatismo. A representação seria geográfica ao invés de basear-se na nacionalidade. Proclamando-se por uma "Rússia, Una e Indivisível", os cadetes viam manifestações de nacionalismo como sinais de deslealdade pró-germânica. Pavel Miliukov afirmou a seus companheiros cadetes, em maio: "O Partido da Liberdade dos Povos engendrará esforços para encontrar uma solução que, dando uma oportunidade às várias regiões da Rússia para criar sua autonomia local com base no princípio da legislação local, ao mesmo tempo não destruirá a unidade do estado russo. A preservação da unidade do Estado russo é o fator limitante, que condiciona as decisões do Partido. A divisão do país em unidades independentes, soberanas, é considerada pelo Partido absolutamente inadmissível".

Os cadetes viam-se como os campeões dos direitos iguais para o povo antes que para os povos, mas a favor de um Estado russo unitário. Miliukov apoiava a hegemonia russa em um Estado multinacional, embora quisesse terminar com as restrições nacionais, como as impostas pelo czarismo, porque inibiam o processo de natural assimilação das minorias. Ainda mais conservadores do que o governo provisório, o qual prometera independência para a Polônia, os cadetes estavam 
preparados para conceder autonomia somente à Polônia, fixando a linha do limite na Ucrânia. Miliukov e Kokoshkin afirmaram a uma delegação do Congresso Nacional Ucraniano, em finais de abril, que a autonomia territorial constituía um perigo para a unidade da Rússia e que os ucranianos não estavam preparados para a independência.

Em grau maior que os seus líderes na capital, os cadetes provincianos viam a Revolução de Fevereiro “como um meio de 'liberar' as nacionalidades não-russas; e, a despeito da adesão do programa do partido a um sistema centralizado, nãofederal de governo, alguns cadetes expressaram-se localmente a favor de uma nova Federação republicana". "Em alguma medida..." (escreve William G. Rosenberg) "os direitos de ucranianos, georgianos e outras minorias nacionais eram subordinados, na prática cadete aos dos grão-russos, uma postura de imperialismo interno que há muito caracterizava o próprio czarismo e que causaria uma continuação de dificuldades aos líderes cadetes em 1917, mesmo nas fileiras de seu próprio partido". No outono de 1917, cadetes importantes, não surpreendentemente, tornaram-se aliados políticos dos cossacos, tradicionais defensores da cidadania russa.

Assim como nas questões de guerra e paz e nas de legislação política e social, também nos problemas dos não-russos, o órgão líder da demokratiia, o soviet de Petrogrado raramente concordava com o governo. Mesmo durante o período de coalisão, os representantes dos partidos socialistas moderados desenvolveram uma política distinta com relação aos não-russos, que refletia tanto posições pré-revolucionárias de seus partidos quanto maior sensibilidade às aspirações dos não-russos. O Partido dos Socialistas Revolucionários declarou em seu primeiro congresso, realizado no ano de 1906, em Imatra, Finlândia, o incondicional direito à autodeterminação nacional, que incluía o direito de separação política da Rússia. Embora algumas vozes isoladas defendessem a subordinação dos direitos das nações à missão da revolução socialista, elas foram efetivamente silenciadas por esmagadora maioria. Enquanto a questão nacional não constituía uma preocupação maior para os neopopulistas, o partido era claro em relação aos seus compromissos com o federalismo - em contraste com os social-democratas que apoiavam um Estado unitário - e à sua oposição à coerção para preservar o império. Mas, de acordo com Oliver Radkey, "em 1906, os socialistas revolucionários eram um partido sem responsabilidade; em 1917, eles assumiram responsabilidade; e, quando examinaram o problema das nacionalidades de suas posições de governo, eles o conceberam com um espírito menos generoso que o dos anos que precederam o triunfo da revolução".

Em 1917 o partido continuava a favor do federalismo, mas agora opunha-se à separação. No terceiro congresso do partido, em maio de 1917, o relator sobre organização estatal (o socialista revolucionário de direita M.V. Vishniak) viu a Rússia como uma Suíça com grande mandado, um Estado federal com um executivo colegiado mas, não obstante, um Estado único: um Estado parlamentar, antes que um parlamento de Estados (um Bundesstaat, antes que um Staatenbund). Máxima autonomia nacional seria acomodada na Federação (até moeda e sistema postal separados, mas sem barreiras tarifárias), mas a secessão não seria permissível. Dentro 
desses limites, a autonomia seria determinada com base em acordos mútuos. A independência seria concedida somente à Polônia; a Finlândia continuaria vinculada à Rússia por razões de ordem estratégica. Quando questionado sobre esse anômalo tratamento da Finlândia, Vishniak respondeu que a independência finlandesa constituiria um perigoso precedente e encorajaria pretensões separatistas de outras nacionalidades. Na questão das nacionalidades, o partido como um todo seguiu a linha da direita e rejeitou o apoio da esquerda à secessão. Até o centrista Viktor Chernov concordou que a Assembléia Constituinte Pan-Russa deveria primeiro formular os critérios segundo os quais as assembléias nacionais poderiam elaborar suas próprias demandas por autonomia.

A social democracia estava comprometida com a autodeterminação nacional e Lênin levou essa bandeira mais longe - a separação do império. Em contraste com o Bund judeu e o Dashnaktsutiun armênio, que advogavam a posição austro-marxista de autonomia nacional-cultural extraterritorial para as etnias (cada nacionalidade seria representada no parlamento independentemente de onde residissem os seus membros), os bolcheviques rejeitaram a idéia de autonomia cultural em favor de autonomia regional não-étnica. Lênin era também firme em sua resistência ao federalismo. No ano revolucionário, a posição bolchevique ofereceu às nacionalidades uma escolha dura: ou completa independência e separação do resto da Rússia, ou tornar-se parte de um Estado socialista unitário com todos os direitos civis e culturais garantidos ao povo trabalhador. Lênin acreditava que o separatismo nacional seria reduzido pela tolerância russa e apoio à completa autodeterminação nacional até o ponto da independência. Somente em 1918 os bolcheviques mudaram sua posição em favor de um Estado federal, no qual as nacionalidades teriam suas pátrias nacionais territoriais.

Ambos, o governo provisório e o soviet de Petrogrado estavam comprometidos com a independência formal e completa da Polônia. Como a Alemanha detinha o controle da maior parte da Polônia no começo de 1917, o apoio político à independência polonesa, de maneira alguma ameaçava o esforço de guerra. Mas a concessão à Polônia só aumentou o apetite de finlandeses e ucranianos, e o conflito inerente entre o princípio de autodeterminação nacional e o comprometimento dos mais importantes atores políticos à unidade do Estado russo emergiu em luta política aberta nas primeiras semanas da revolução.

O manifesto do governo, que restaurou a Constituição da Finlândia, reconheceu a completa "independência interna" do antigo grão-ducado, mas declarou o governo de Petrogrado como "o detentor de pleno poder soberano". A liderança social-democrata do parlamento finlandês rapidamente propôs que, com a queda da monarquia, a soberania deveria passar ao governo finlandês, embora concordando que temporariamente o governo provisório continuasse decidindo sobre a política exterior e militar. O futuro bolchevique Otto Kuusinen concluiu que a minuta da Constituição daria à Finlândia "tudo o que se poderia desejar e era melhor que a independência". A reação em Petrogrado à ação finlandesa, entretanto, foi rápida, dura e negativa. A política russa, tal como formulada por Kerensky, 
rejeitou qualquer pronunciamento firme sobre o status final da Finlândia até a reunião da Assembléia Constituinte Pan-Russa. A posição do governo foi apoiada pelos socialistas moderados nos sovietes. Quando, no começo de abril, os socialdemocratas finlandeses encontraram-se com os líderes mencheviques, os últimos reconheceram o direito da Finlândia à autodeterminação, mas mantiveram que somente a Assembléia Constituinte poderia, em última instância, determinar a questão.

O único partido importante a apoiar a completa independência da Finlândia foi o bolchevique. Tão cedo como 11 de março, Lênin, ainda na Suíça, defendeu que "o proletariado russo garantirá completa liberdade à Finlândia, inclusive a liberdade à secessão". Lênin disse à sétima conferência dos bolcheviques, realizada em abril: "Nossa atitute com relação ao movimento separatista é indiferente, neutra... Somos a favor de a Finlândia receber completa liberdade porque então haverá maior confiança na democracia russa e os finlandeses não se separarão".

A atitude das autoridades de Petrogrado estimularam ainda maior apoio à independência na Finlândia e, durante maio e junho, os social-democratas finlandeses lutaram por uma lei (a valtalaki) que concedia soberania ao parlamento (seim) finlandês. Os socialistas russos, entretanto, esperavam postergar a disposição final da Finlândia até a Assembléia Constituinte. O primeiro Congresso Pan-Russo dos Sovietes adotou uma ampla resolução sobre a questão nacional, proclamando seu apoio à descentralização do Estado e à ampla autonomia política para as nações que diferiam étnica e socio-economicamente umas das outras. Conclamou o governo a emitir uma declaração reconhecendo o direito à autodeterminação de todos os povos, incluindo separação, mas deixou que a disposição final das várias regiões fosse realizada por meio de uma reunião com a Assembléia Nacional Constituinte. Até os últimos dias de sua existência, o governo provisório recusou-se a conceder completa independência à Finlândia e mostrou-se disposto a empregar a força armada para garantir a sua política.

O governo provisório subordinou os princípios de autodeterminação e escolha democrática à preservação do território do império. Os socialistas moderados concordaram com a estratégia do governo. A maioria dos povos do império russo não estava tão determinada em 1917 a separar-se do novo Estado democrático. A sua fé jazia em uma solução constitucional, num Estado multinacional renovado, que sobrepujava a arriscada escolha de seguir só em tempos de guerra. Em Kiev, entretanto, uma assembléia localmente eleita, a Rada, emitiu sua Primeira Universal, declarando autonomia para a Ucrânia e concedendo-se a suprema autoridade política. No final de junho, delegados do governo reuniram-se em Kiev com representantes da Rada e, após acaloradas discussões, a delegação de Petrogrado relutantemente decidiu reconhecer a competência da Rada para formular as reformas na Ucrânia e dirigir a região até a convocação da Assembléia Constituinte. Essa tentativa de compromisso levou à crise de julho, em Petrogrado, quando inúmeros membros do partido dos cadetes pediram demissão do governo em protesto contra as concessões feitas a favor da autonomia da Ucrânia. 
O nacionalismo era relativamente fraco no primeiro ano revolucionário, ainda grandemente centrado na inteligentsia étnica, entre os estudantes e as baixas classes médias urbanas, passando fugazmente entre estratos mais amplos. Entre bielo-russos, lituanos e azerbadjãos, mais que um senso de nacionalidade, a identificação mais importante era com o povo mais próximo com quem era compartilhada uma comunhão social e religiosa. Para esses povos, nem o nacionalismo nem o socialismo eram capazes de mobilizar grandes números para a luta política que decidiria seu futuro. Para inúmeras nacionalidades - entre elas os letãos e os georgianos - os movimentos socialistas de base de classe eram muito mais potentes que o nacionalismo político. Para outras - como os ucranianos e os estonianos -, a nacionalidade competia com um senso de classe pela primeira lealdade de trabalhadores e camponeses, sem que qualquer deles ganhasse uma posição dominante. Entre os armênios, dominava um partido socialista nacionalista, o Dashnaktsutiun, e frente à ameaça de aniquilação nas mãos dos turcos otomanos, reuniram-se em torno de um nacionalismo inclusivo, de todas as classes. A escolha para a Rússia revolucionária de 1917 era entre manter o império ou criar um novo Estado democrático, o que requeria dar às nações a opção de separar-se, mas deixando o Estado. Desde os tempos da Revolução Francesa, o discurso da nação incluía idéias de soberania popular e igualdade sob a lei. $\mathrm{O}$ nacionalismo rejeitava as relações desiguais inerentes ao império e lutava por completa igualdade legal e representação dos povos subordinados. Ambos, liberais e socialistas, acreditavam na autodeterminação como uma linguagem política, mas, quando não-russos, optaram pela separação; os interesses do Estado ganharam precedência sobre os princípios.

\section{Outubro e os povos não-russos}

Já no apelo $A$ todos os trabalhadores muçulmanos da Rússia e do Oriente, lançado apenas um mês após a chegada dos bolcheviques ao poder, a poderosa retórica da autodeterminação, liberação, independência e antiimperialismo estabeleceu uma unidade na luta contra a opressão nacional e colonial. Como o Exército Vermelho estava engajado por grande parte do período da guerra civil russa numa batalha simultânea contra os burgueses nacionalistas e os intervencionistas estrangeiros, o antiimperialismo não se distinguia do esforço para libertar os antigos povos do império russo. A Rússia soviética fora concebida não como um Estado nacional comum, mas como uma primeira pedra em um futuro edifício multinacional socialista. O alcance da Revolução Russa deveria ser ilimitado. O que os seus inimigos mais tarde construiriam em uma potente imagem ideológica de esforço para dominação do mundo era, em sua encarnação, um esforço dirigido primeiramente contra o imperialismo britânico. Tal esforço levou Lênin e seus camaradas a uma série de peculiares alianças com o caído líder turco Enver Pasha, com o rei Amanullah no Afganistão, com o rebelde Kuchuk Khan no norte da Pérsia, com Kemal Pasha na Anatólia e com outros nacionalistas não-socialistas. Os impérios dos europeus na Ásia, a periferia semicolonial da Pérsia, da China e da Turquia (na conceitualização de Lênin), e os novos Estados independentes estabelecidos após a Revolução de Outubro, como eram dependentes da presença e do apoio do poder europeu, 
todos eram compreendidos de uma única forma, como o último esteio do moribundo capitalismo. Com uma confiança nascida das vitórias recentes e da fé em uma escatologia marxista, e com um oportunismo enraizado nos limitados recursos à mão, os bolcheviques usaram de todos os meios disponíveis para realizar o seu sonho da revolução internacional. Para os comunistas do período da guerra civil, o internacionalismo era menos servidor do Estado soviético do que o Estado soviético servidor do internacionalismo.

Desde o começo, a refrega entre nacionalismo e socialismo foi uma batalha entre os que apoiavam o governo soviético e os intervencionistas estrangeiros, que esperavam ganhar aliados na luta contra os vermelhos. Um prístino nacionalismo, capaz de estabelecer uma firme base de apoio na população étnica e de manter a independência política sem ajuda estrangeira, era difícil de ser encontrado nas periferias do império russo. Dois discursos ferozmente antagônicos se confrontavam numa batalha de retórica e violência: os nacionalistas apelavam para o Ocidente para defender o seu direito à autodeterminação nacional contra uma ameaça russa renovada, enquanto os comunistas retratavam os nacionalistas e seus suportes estrangeiros como parte de um esforço imperialista para conter e destruir o bolchevismo e a vindoura revolução internacional.

No começo do século XX, quando os social-democratas agonizavam sobre a emergente questão nacional, os marxistas russos procuraram ao mesmo tempo ganhar aliados entre as nacionalidades não-russas e combater as tentativas nacionalistas de romper o Estado unitário. Seguros em sua fé, de que "as diferenças nacionais e os antagonismos entre os povos desaparecerão gradualmente de dia para dia" e de que "a supremacia do proletariado levará ao seu mais rápido desaparecimento", os teóricos bolcheviques eram contrários a soluções políticas que pudessem desviar o que eles entendiam ser o fluxo da história e promovessem a identidade étnica. Lênin, Stálin, o bolchevique armênio Stepan Shahumian, entre outros, eram firmes em sua oposição ao federalismo, ao princípio austro-marxista de autonomia nacional cultural extraterritorial (cada nacionalidade representada no parlamento, independentemente do local em que vivem os seus membros) e ao princípio nacionalista moderado de autonomia nacional cultural territorial (etnia definindo unidades políticas territoriais autônomas). Os leninistas preferiram a autonomia regional, na qual as unidades políticas não teriam designações étnicas. A solução proletária para a questão nacional preservaria a unidade do Estado e, ao mesmo tempo, permitiria o autogoverno local, garantindo completa liberdade cultural e lingüística no interior do Estado socialista. Embora a autodeterminação nacional significasse, para Lênin, que uma nacionalidade poderia optar por se tornar completamente independente, em sua formulação pré-1917 as nacionalidades que permanecessem no interior do Estado socialista não teriam o direito a um território político autonômo, nem o direito a uma relação federativa com o centro.

O pensamento pré-revolucionário dos bolcheviques não sobreviveu intacto à revolução. O novo Estado soviético era ao mesmo tempo federativo, ao menos em nome e teoria, e baseado em unidades políticas étnicas. De fato, por mais de 
uma década seguinte à guerra civil, nacionalidades como os judeus e os armênios, e os ucranianos na Rússia, gozaram de privilégios extraterritoriais, com suas próprias escolas e sovietes operando em repúblicas de outras nacionalidades. A prática soviética constituiu um compromisso com o máximo desiderato ideológico. E a grande expectativa de que tais concessões ao princípio nacional conduzissem à consolidação da etnia ao invés de seu desaparecimento provou ser correta para as maiores nacionalidades. Ao invés de cadinho, a União Soviética tornou-se incubador de novas nações.

Embora muitos de seus camaradas fossem consistentemente a favor de subordinar o nacionalismo estritamente a considerações de classe, Lênin, ao mesmo tempo, tinha consciência do poder do nacionalismo (mesmo se tivesse esperança de subordiná-lo à revolução proletária) e estava pronto a concordar com a necessidade de aliar-se com os nacionalistas burgueses. Para ele, nacionalismo e separatismo não eram nem naturais nem inevitáveis, mas contingentes no sentido da opressão que as nacionalidades sofriam do imperialismo. Permaneceu convencido de que o nacionalismo refletia somente os interesses da burguesia, que os verdadeiros interesses do proletariado eram supranacionais e que o fim do colonialismo diminuiria o poder dos sentimentos nacionalistas (2).

Em contraposição aos seus companheiros da esquerda, Lênin recusou-se a se opor à independência da Finlândia, da Polônia e da Ucrânia. Embora tivesse esperança de que tais separações pudessem ser evitadas e se reservasse a opção de opor-se a passos específicos em direção à independência, inicialmente abjurou o princípio da força para manter o império como um todo. Ele foi inequívoco em seu compromisso público com relação ao "completo direito de separação da Rússia, de todas as nações e nacionalidades oprimidas pelo czarismo e unidas pela força ou mantidas pela força entre os limites do Estado, isso é, anexadas". Ao mesmo tempo, Lênin defendia a idéia de que o objetivo do partido do proletariado era a criação do maior Estado possível e a aproximação (sblizenie) e eventual fusão (sliianie) das nações. Tal objetivo deveria ser alcançado não através da força, mas voluntariamente, pelo desejo dos trabalhadores. Já no começo de 1917 moderou sua posição primitiva e propôs que uma autonomia completa (e nacional) fosse garantida no novo Estado (3).

Imediatamente após a tomada do poder, os bolcheviques instituíram o Comissariado do Povo para as Nacionalidades, sob o comando de Stálin, e emitiram uma série de declarações sobre "os direitos dos trabalhadores e povos explorados... a todos os trabalhadores muçulmanos da Rússia e do Oriente" e sobre a disposição da Armênia turca. Mais importante, com pouca habilidade real para assegurar a sua vontade nas periferias, o governo soviético deu um passo estratégico em resposta ao número crescente de autonomias e aceitou, em janeiro de 1918, o princípio do federalismo. Ao lançar um ataque à Ucrânia, os bolcheviques anunciaram que eles reconheciam o Comitê Central Executivo dos Sovietes da Ucrânia, como "a suprema autoridade na Ucrânia" e aceitavam "uma união federal com a Rússia e completa unidade em questões de política interna e externa". No final do 
mês, o Terceiro Congresso dos Sovietes resolveu: "A República Soviética Russa é estabelecida na base de uma união livre de nações, como uma federação de repúblicas nacionais soviéticas". Ambos, o federalismo e a autonomia nacional territorial, foram inscritos na primeira Constituição soviética, adotada em julho de 1918. Como Richard Pipes observou, "a Rússia soviética... tornou-se o primeiro Estado moderno a colocar o princípio nacional na base de sua estrutura federal" (4).

$\mathrm{Na}$ ferocidade da guerra civil, muitos comunistas, particularmente na periferia ou de origem não-russa, opuseram-se à posição de princípio de Lênin a favor da autodeterminação nacional, temendo a dissolução do Estado unitário. Em dezembro de 1917, Stálin defendeu a idéia de que a liberdade de autodeterminação deveria ser dada somente às classes trabalhadoras, não à burguesia. No $8^{\circ}$ Congresso do partido, realizado em março de 1919, Bukharin apoiou a posição de Stálin e tentou separar a questão nacional da questão colonial. Somente nas nações em que o proletariado não tivesse definido seus interesses separadamente dos da burguesia deveria o slogan da autodeterminação das nações ser empregado.

A formula de Lênin, ele argumentava, era apropriada somente para os "hottentotes, os bosquimanos, os negros, os índios", enquanto a noção de autodeterminação para as classes trabalhadoras correspondia ao período em que a ditadura do proletariado estava sendo estabelecida (5). Lênin respondeu a Bukharin asperamente. "Não há bosquimanos na Rússia; no que concerne os hottentotes, eu também não ouvi que têm pretensões a uma república autonôma, mas nós temos os barshkirstãos, os quirguistãos, uma série de outros povos, cujo reconhecimento não podemos ignorar". Todas as nações, ele reafirmou, têm o direito à autodeterminação, e o apoio dos bolcheviques a este princípio ajudaria a autodeterminação das classes trabalhadoras. O estágio de uma dada nação, quando passa de "formas medievais para a democracia burguesa e depois para a democracia proletária", ele afirmou, "deveria ser considerada", mas era difícil diferenciar os interesses do proletariado e da burguesia, o que tinha sido definido somente na Rússia (6).

A resolução final do Congresso foi um compromisso entre a tolerância ao nacionalismo de Lênin e a oposição mais militante contra ela. Mantendo o princípio da autodeterminação nacional, a resolução dizia: "No que concerne à questão sobre quem é o condutor dos desejos de separação da nação, o PCR se posiciona no ponto de vista histórico de classes, levando em consideração o nível do desenvolvimento histórico em que se situa uma dada nação"(7).

Os bolcheviques não alcançaram consenso na política das nacionalidades e o conflito entre os que, como Lênin, levavam em consideração a agenda nacional dos não-russos e aqueles que, como Stálin, subordinavam o nacional ao proletário continuou até a morte do primeiro e a consolidação do poder do último no interior do partido. Na base, os comunistas decidiram eles mesmos quem era o condutor da vontade da nação e, após o reconhecimento inicial da independência para a Finlândia, a Polônia, as repúblicas Bálticas e (pelo momento) a Georgia, poucos gestos mais foram feitos em direção aos separatistas. 
Por volta do final de 1919, enquanto refletia sobre os fatores que conduziram à vitória bolchevique em 1917, Lênin retornou à Ucrânia para sublinhar a importância da tolerância na política das nacionalidades. Revendo os resultados das eleições para a Assembléia Constituinte, nas quais os revolucionários socialistas ucranianos e os socialistas venceram os revolucionários socialistas russos, ele observou: "A divisão entre os revolucionários socialistas russos e ucranianos já em 1917 não pode ter sido acidental". Sem defender a idéia de que os sentimentos nacionais são fixos ou permanentes, sugeriu uma vez mais que os internacionalistas precisam ser tolerantes à cambiante consciência nacional dos não-russos, a qual, ele acreditava, era parte da vacilação da pequena burguesia, que tinha sido uma característica do campesinato ao longo da guerra civil.

"A questão de se a Ucrânia será um Estado separado é muito menos importante [que os interesses fundamentais da ditadura do proletariado, a unidade do Exército Vermelho ou o papel de liderança do proletariado com relação ao campesinato]. Nós não devemos ficar surpresos ou atemorizados, até mesmo pela perspectiva de os trabalhadores e camponeses ucranianos tentarem sistemas diferentes e, no curso de alguns anos, testarem através da prática uma união com a Rússia, ou separarem-se da última e formarem uma república soviética socialista ucraniana independente, ou varias formas de sua mais próxima aliança (...) A vacilação do povo trabalhador não-proletário em tal questão é natural, até mesmo inevitável, mas não é menos temível para o proletariado. É dever do proletário que é realmente capaz de ser um internacionalista... de deixar às próprias massas não proletárias, de livrar-se dessa vacilação como resultado de sua própria experiência" (8).

Assim que a situação estratégica melhorou para os bolcheviques e seus aliados, no verão de 1920, a questão nacional e colonial foi diretamente colocada na agenda. Os britânicos estavam deixando a periferia russa e o comunismo ganhou o seu primeiro ponto de apoio no Cáucaso, com a sovietização relativamente fácil do Azerbadjão, em abril. O balanço de forças na Ásia Central e na Transcaucásia, onde a Georgia e a Armênia permaneciam independentes, era claramente a favor dos soviéticos, e vínculos diretos foram estabelecidos entre os soviéticos e os kemalistas nacionalistas na Anatólia. Em 26 de abril Kemal enviou uma comunicação oficial a Moscou, expressando sua apreciação à luta de Moscou contra o imperialismo e sua prontidão para assumir responsabilidade por "operações militares contra o governo imperialista da Armênia" e para encorajar o Azerbadjão "a entrar na união estatal bolchevique" (9).

Em maio, tropas soviéticas e o revolucionário persa Kuchuk Khan estabeleceram a república soviética do Gilan, na costa sul do mar Cáspio e, embora a situação na Pérsia continuasse extraordinariamente fluida, o governo de Teheran pareceu preparado para distanciar-se do britânico e abrir negociações com os soviéticos. Com Denikin derrotado, Kolchak morto e o Exército Vermelho marchando contra a Polônia de Pilsutski, a última metade dos anos 20 revelou-se como o ponto alto do entusiasmo revolucionário e da promoção bolchevique direta da revolução no Oriente. 


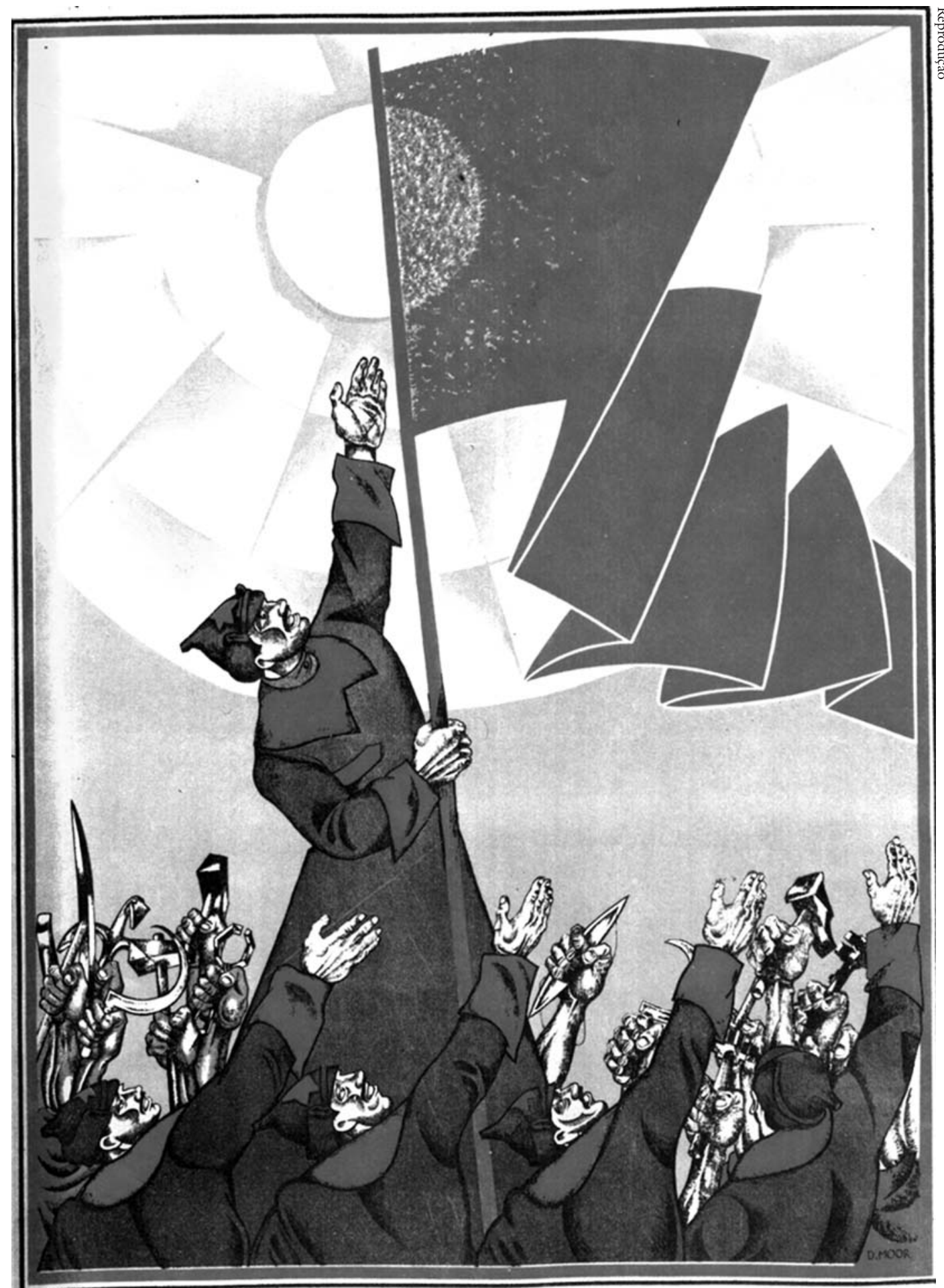

TОРЖЕСТВЕННОЕ ОБЕЩАНИЕ

Promessa solene festiva, por D. Moor, 1918 
Inúmeros temas reafirmaram-se repetidamente nas discussões em torno da questão nacional e colonial em 1920, no Segundo Congresso da Internacional Comunista e no Congresso dos Povos do Oriente, em Baku.

O primeiro foi o tema condutor de Lênin, que freqüentou os seus escritos desde 1914 - a relação entre o imperialismo capitalista e a crise revolucionária em ambos os mundos avançado e colonial. Além de um bilhão de pessoas vivendo em Estados coloniais e semicoloniais, e outro quarto de bilhão vivendo na Rússia, a Alemanha, a Áustria e a Bulgária, desde a guerra - ele defendeu - estavam relegadas "ao que corresponde a um status colonial". Os "superlucros de milhares de milhões formam a base econômica na qual o oportunismo no movimento trabalhista é construído" (10). A dependência do mundo colonial e semicolonial à metrópole capitalista foi reconhecida por todos os comunistas, mas alguns deles não-europeus, como o hindú M.N. Roy e "muitos camaradas do Turquestão" (a quem foi feita referência pelo delegado iraniano Sultan Zade no Segundo Congresso Mundial), foram além e defenderam a idéia de que a revolução na Europa requeria uma revolução no Oriente.

O segundo tema reafirmado foi a falha da Segunda Internacional em enfocar a questão nacional de maneira revolucionária. Lênin, Roy, Sultan Zade, entre outros, retrataram os social-democratas como reformistas eurocentristas, desejosos de apoiar os movimentos pelo autogoverno nas colônias, mas relutantes em apoiar os esforços revolucionários. Os comunistas, por sua vez, reconheceram a necessidade de colaboração entre os revolucionários na Europa, na América e na Ásia, e orgulharam-se da representação multirracial nas reuniões do Comintern.

Um terceiro tema dominante referia-se à diferença histórica entre a democracia burguesa, apoiada pelos social-democratas da Europa e pela democracia soviética, e o forte senso de que se tinha aberto uma nova época histórica, a qual tornou o parlamentarismo obsoleto (11). Em suas Teses preliminares sobre a questão nacional e colonial, Lênin começou com a distinção entre a democracia formal burguesa, que propicia tudo sob igualdade jurídica para todos, e o "real significado da demanda por igualdade", que requeria abolição das classes (12). A democracia burguesa também escondia a exploração das nações mais fracas pelas mais fortes, embora a guerra de 1914-18 tivesse exposto tal hipocrisia. Somente uma luta comum, de todos os proletários e do povo trabalhador de todas as nações poderia derrubar o domínio dos grandes proprietários de terra e da burguesia.

Ainda outro, dizia respeito à natureza do futuro Estado socialista, uma grande Federação multinacional não dessemelhante da República Soviética Federativa Socialista da Rússia (RSFSR). A Federação, sustentava Lênin, era a forma avançada para a completa unidade dos trabalhadores dos diferentes países. A Federação já tinha mostrado a sua utilidade na prática, nas relações da RSFSR com outras repúblicas soviéticas (Hungria, Finlândia e Letônia no passado; Azerbadjão e Ucrânia, no presente) e no interior da Rússia, nas relações com as nacionalidades que antes não tinham existência estatal, nem autonomia (por exemplo, as repúblicas autônomas 
Tártara e de Bashkir na RSFSR). Era essencial trabalhar por uma união federativa mais firme, tanto política quanto economicamente; mas, ao mesmo tempo, advertia Lênin, completo reconhecimento dos direitos das nações e minorias, inclusive o direito a Estados separados deveria ser apoiado.

Diferenças de tom e de direção apareceram nas discussões das estratégias apropriadas para ganhar as massas do Oriente. Em suas teses originais, apresentadas ao Segundo Congresso do Komintern, Lênin sustentou que "todos os partidos comunistas precisam ajudar a libertação democrático-burguesa" nos países atrasados com relações patriarcais ou feudais. Enquanto lutam contra os elementos da reação clerical e medieval, contra o pan-islamismo e outros movimentos que tentam unir o movimento de libertação fortalecendo os kahns, os grandes donos de terra, os mullahs etc., os comunistas devem apoiar o movimento camponês contra os grandes donos de terra, formando uma aliança provisória com a democracia burguesa das colônias e dos países atrasados.

Quando Lênin submeteu tais teses aos seus camaradas, encontrou resistência à sua aliança provisória com a burguesia nacional. Assegurou aos que duvidavam que "a aliança com o campesinato é mais fortemente sublinhada para mim (e isso não é completamente igual com relação à burguesia)" (13).

De forma mais vociferante, Roy discutiu o apoio de Lênin à burguesia nacional e sustentou que ele estava errado em acreditar que o movimento de libertação nacional tivesse o significado da revolução democrático-burguesa. Embora ainda um revolucionário não provado, Roy (como ele nos conta em suas memórias), "mostrou que a burguesia, como classe, mesmo nos países coloniais mais avançados, como a Índia, não se diferenciava econômica e culturalmente da ordem social feudal; por isso o movimento nacionalista era ideologicamente reacionário, no sentido de que o triunfo não representaria necessariamente uma revolução democrático-burguesa. O papel de Ghandi era o ponto crucial de diferença. Lênin acreditava que, como inspirador e líder de um movimento de massas, ele era um revolucionário. Eu sustentei então, que como predicante religioso e cultural, ele era constrangido a ser socialmente reacionário, não importando quão revolucionário ele pudesse parecer politicamente" (14).

Após inúmeras discussões privadas com Roy e um debate geral na Comissão sobre a Questãa Nacional e Colonial, Lênin admitiu que seus pontos de vista haviam sido mudados diante do desafio de Roy (15). Este sustentou que "a dominação estrangeira constantemente obstaculiza o livre desenvolvimento da vida social; por isso, o primeiro passo da revolução deve ser a remoção desta dominação estrangeira. A luta para derrubar a dominação estrangeira nas colonias não deve, portanto, significar a subscrição dos objetivos nacionais da burguesia nacional mas muito mais a facilitação do caminho para a liberação do proletariado das colonias".

Roy distinguia mais claramente do que Lênin os dois movimentos oponentes no mundo colonial: "O movimento nacionalista democrático-burguês, que segue o programa da libertação política com a conservação da ordem capitalista; [e] 
a luta dos camponeses despossuídos por sua libertação de qualquer tipo de exploração" (16). Os comunistas não devem permitir ao primeiro dominar o segundo e precisam aliar-se e apoiar o segundo. Lênin concordou que os comunistas deveriam apoiar os movimentos nacional-revolucionários, mas recusar-se a apoiar movimentos reformistas baseados na colaboração com as burguesias colonial e metropolitana. Na ausência de um proletariado, como no Turquestão, o partido comunista deve assumir a liderança "de maneira a despertar um pensamento político e uma ação política independentes (17).

Embora Lênin se mantivesse no princípio da autodeterminação nacional, o seu ajustamento à formulação de Roy teve um efeito político similar aos passos de Stálin e Bukharin no sentido de considerar o estágio que uma nação tinha atingido. Ambos solaparam a autenticidade das reivindicações do nacionalismo e retiraram as restrições que Lênin havia anteriormente proposto. Tais posições mais revolucionárias levaram os comunistas a uma liderança das lutas periféricas e coloniais que dificilmente correspondia à sua força real nessas regiões. Na ausência de um proletariado significativo, em situações nas quais o único movimento revolucionário viável era um que os comunistas não poderiam apoiar totalmente, o partido tornou-se um substituto do proletariado. Ao invés de estar engajado na revolução real, que era anticolonial e conduzida por nacionalistas e socialistas étnicos, o partido construiu uma leitura do momento político que lhes permitiu extraordinária liberdade e os deixou expostos a, precisamente, acusações de expansionismo russo, contra o qual havia prevenido Lênin.

Depois de alguns meses, a república da Armênia, vendo-se face a uma invasão dos turcos kemalistas, capitulou às forças bolcheviques estacionadas em suas fronteiras como o mal menor. Em fevereiro de 1921 o Exército Vermelho expulsou os mencheviques da Georgia. Ambas as revoluções transcaucasianas foram muito mais artificiais e externas do que foi o colapso do Azerbadjão, onde os bolcheviques tiveram considerável apoio dos trabalhadores de Baku. Embora inicialmente os comunistas armênios tenham concordado em trabalhar com os dashnaks e Lênin tenha preferido alguma acomodação com os mencheviques georgianos, em ambos os casos os moderados foram rapidamente eliminados e ordens políticas puramente comunistas foram estabelecidas. Na Transcaucásia, pelo menos, nenhuma tentativa real foi feita para implementar o aspecto mais cauteloso da estratégia do Komintern, qual seja, a de limitada cooperação com os nacionalistas não comunistas. Ao contrario, foi adotada a leitura mais militante dessa estratégia de avanço, tão pronto quanto possível, na direção comunista do movimento. Mas, na Armênia e na Geórgia, onde não havia apoio significativo ao bolchevismo, o partido permaneceu uma força política isolada até que o tempo, a inércia e a coerção trouxessem a aquiescência, de má vontade, da população.

A primeira fase do envolvimento do Komintern com os povos do Oriente terminou no final de 1921. A onda revolucionária retroagiu e o governo soviético começou a ver-se, ele mesmo, como um Estado entre muitos, ainda que com um papel histórico diferente. A ligação entre a questão nacional no interior da URSS e 
a luta antiimperialista no exterior tornou-se mais tênue. Talvez mais ominosamente, à luz de uma resistente realidade, na qual o inevitável movimento em direção ao comunismo parecia paralisado, alargou-se o hiato entre a prática real dos bolcheviques e a inflamada retórica que a disfarçava.

Os bolcheviques constituíam um partido minoritário, o qual representava uma classe social que tinha praticamente desaparecido durante a guerra civil. Sem hegemonia política ou cultural sobre as vastas massas camponesas e com excepcional vulnerabilidade nas regiões não-russas, os partidos comunistas moderaram seu próprio salto para o socialismo. Os anos da NEP - Nova Política Econômica (192128) constituíram um período de compromisso estratégico com o campesinato na Rússia e nas repúblicas nacionais, um tempo de retirada e de paciência esperando a demorada revolução internacional. Lênin continuou a advogar cautela e sensibilidade com relação aos não-russos, enquanto muitos de seus camaradas, mais notavelmente Stálin e Orjonikidze, estavam menos desejosos de acomodar até moderados nacionalistas. Em inúmeras repúblicas, líderes dos partidos derrotados foram rapidamente removidos do poder e enviados ao exílio; mas outros membros dos movimentos nacionalista e socialista moderado foram integrados nos partidos comunistas e nos aparelhos de Estado. O projeto bolchevique agora envolvia a construção de um novo Estado federativo que criaria as nações dentro dele e forjaria novas lealdades aos ideais dos socialistas.

\section{Nações no interior do Império}

Nas raras ocasiões em que a literatura sovietológica (nas décadas desde a Segunda Guerra Mundial até os anos 70) enfocou os povos não-russos, argumentou-se que o Estado soviético tinha efetivamente dominado e integrado as nacionalidades no projeto geral de transformação social. Enquanto o modelo interpretativo dominante permaneceu inteiramente centrado no Estado, analistas concordaram que o resultado do assalto totalitário nas periferias, assim como na sociedade em geral, era atomizar os sujeitos e tornar a resistência impossível. Mesmo quando a ciência social ocidental reviu a industrialização soviética como uma forma alternativa de modernização, manteve-se a expectativa de que os não-russos sucumbiriam às recompensas sociais e aos benefícios materiais da assimilação à cultura soviética. Somente em 1970, começaram alguns poucos estudantes da questão nacional a enfatizar as políticas e processos profundamente contraditórios que estavam gerando novas capacidades de resistência à criação de um único sovetskii narod (povo soviético).

A política leninista das nacionalidades estabeleceu uma referência particular - estruturas estatais baseadas na etnia, políticas de nativização, uma nação pseudo federal - na qual a futura história dos não-russos deveria ser moldada. Embora o objetivo imperial de Moscou sempre tenha ignorado as prerrogativas das repúblicas, tornando sua soberania uma ficção, muitas nacionalidades tornaram-se demograficamente mais consolidadas em suas pátrias, adquiriram efetivas e articuladas elites políticas e intelectuais nacionais, e desenvolveram uma compartilhada consciência 
nacional. Estas nacionalidades mais conscientes e consolidadas estavam enraizadas em territórios específicos, com abundantes privilégios para as nações titulares e suas elites locais comunistas. A transformação econômica e social associada com as brutalidades do stalinismo minaram mas não eliminaram os ganhos culturais e sociais dos não-russos. De fato, muitas formas mais velhas de associação foram preservadas, a despeito das catástrofes da coletivização e dos grandes expurgos.

Com o fim do terror e a redução do hipercentralismo dos anos de Stálin, as elites locais fizeram um esforço maior para governar através da persuasão, de concessões, e distribuindo bens aos seus cidadãos. Maior permissividade à expressão nacionalista foi acompanhada, em muitas repúblicas, da montagem de redes de parentesco e clãs do tipo da máfia, que vincularam o poder político local com a expansão da segunda economia. A corrupção crescente nas repúblicas foi sancionada no período final de Brezhnev pelo topo do partido, e a degeneração do sistema estava bem avançada quando uma nova geração de líderes tentou deter a decadência.

As políticas e processos que fortaleceram as nacionalidades em suas próprias repúblicas conflitavam profundamente com os processos e políticas contraditórios que atraíam os não-russos para a aculturação, até mesmo assimilação à cultura soviética russificada. Nas repúblicas soviéticas ocidentais, a russificação cobrou direitos nos períodos stalinista e pós-stalinista. Muitos não-russos, especialmente intelectuais, ficaram ansiosos com relação à sempre presente ameaça ao nacional, partida das políticas estatais e práticas do regime soviético. Nas últimas décadas do Estado soviético a desilusão crescente na sociedade com os objetivos e a competência dos líderes soviéticos expressou-se crescentemente no idioma do nacionalismo. Por sua própria usurpação da linguagem de classe, o Estado soviético deslegitimou-a como retórica de dissenso e, ironicamente, autorizou a etnia como um modo alternativo de expressão de oposição.

Pode-se argumentar que o nacionalismo tem tido uma presença crescente em todas as partes do mundo em nosso século, que os processos de urbanização e industrialização, a difusão da educação de massas e o maior acesso à mídia impressa e outra ajudam a consolidação dos grupos etno-lingüísticos - todos dentro de um poderoso e universal discurso da nação. Mas a criação da nação na URSS ocorreu em um único contexto: um Estado que se tinha proposto superar o nacionalismo e as diferenças entre as nações criou de fato um conjunto de instituições e iniciou processos que apressaram o desenvolvimento de nacionalidades conscientes, seculares e politicamente mobilizáveis. A despeito dos objetivos postos pelo partido comunista, os processos de nativização, industrializacão, urbanização e construção do Estado na União Soviética forneceram a base social e cultural, inicialmente, para as elites étnicas organizarem uma pequena resistência e, posteriormente, para as contra-elites mobilizarem movimentos nacionalistas de ampla base.

Entretanto, o desafio aberto ao império surgiu somente depois que o topo da liderança partidária decidiu reformar radicalmente o sistema político, somente quando os próprios comunistas começaram um processo que deslegitimou o sistema soviético e concedeu uma voz política à alternativa nacionalista. 
Notas

1 Administrações locais e provinciais dirigidas pela nobreza e a burguesia na Rússia czarista (nota do tradutor).

2 "Nós dizemos aos ucranianos: como ucranianos vocês podem conduzir as suas vidas como quiserem. Mas nós estendemos uma mão fraternal aos trabalhadores ucranianos e lhes dizemos: junto com vocês nós combateremos contra a sua e a nossa burguesia. Somente uma aliança socialista de trabalhadores de todos os países elimina toda a base para a perseguição e a luta nacionais" (V.I.Lênin. Polnoe sobranie sochinenii. Moscou, 1959-19-. Daqui para frente, PSS. XXXV, p.116).

3 Da brochura Zadachi proletariata v nashei revolutsii (Proekt platformy proletarskoi partii), escrita em abril de 1917, e primeiramente editada em setembro (V.I. Lênin, PSS, XXXI, p. 167-168).

4 Richard Pipes. The formation of the Soviet Union, p. 11.

5 Vosmoi s'ezd RKP(b). Mart 1919 goda. Protokoly. Moscou, Gosudarstvennoe izdatel'stvo politicheskoi literatury, 1959, p. 46-48.

$6 \mathrm{Ib}$, p. $52-56$.

7 Ib., p. 397-398.

8 Lênin, PSS, XL, p.20. Collected Works, XXX, p. 271.

9 Richard G. Hovannisian, Armenia and the Caucasus in the genesis of the SovietTurkish Entente. International Journal of Middle East Studies, IV, p. 147, 1973.

$10 \mathrm{Ib} ., \mathrm{p} .15,27$.

11 SECOND CONGRESS OF THE COMMUNIST INTERNATIONAL. Minutes of the Proceedings. London, New Park, 1977, p.11.

12 Pervonachal'nyi nabrosok tezisov po natsional'nomu i kolonial'nomu voprosam. In: V.I. Lênin, Polnoe sobranie sochinenii (5th ed.), XLI, p. 161-168.

13 Stálin, em uma carta datada de 12 de junho de 1920, escreveu a Lênin que ele deveria incluir a idéia de Confederação como o passo de transição no caminho de juntar diferentes nações em uma única unidade política. A Federação soviética (RSFSR) era apropriada para as nacionalidades que faziam parte da antiga Rússia, mas não para aquelas que tinham sido independentes. Observou que não existiam diferenças entre as relações federativas no interior da RSFSR e entre a RSFSR e outras repúblicas soviéticas; ou que elas eram tão poucas que não significavam nada (net, ili ona tak mala, chto ravniaetsia nuliu). Lênin, PPS, XLI, p. 513). Esta idéia foi mais tarde trazida na noção de Stálin de autonomização (A carta de Stálin é disponível em tradução inglesa em Xenia Joukoff Eudin \& Robert C. North, Soviet Russia and East. 1920-1917: a documentary survey. Stanford, Stanford University Press, 1957, p. 67-68).

14 M.N. Roy's memoirs. Bombay, Allied Publishers, 1964, p.379.

$15 \mathrm{Ib}, \mathrm{p} .380$. 
16 SECOND CONGRESS OF THE COMMUNIST INTERNATIONAL. Minutes of the Proceedings. London, New Park, 1977, p. 117.

17 Ib., p. 110-112. Embora o próprio Roy tenha posteriormente sublinhado a mudança de Lênin em direção à sua posição, a comparação entre a sua minuta original e as teses, tais como apresentadas no Congresso, mostram significativo ajustamento também na sua posição. Diante do Congresso, Roy assumiu uma posição mais direta sobre a primazia da revolução extra-européia, escrevendo: "A fonte principal da qual o capitalismo retira sua força mais importante não se encontra mais nos países industriais, mas nas possessões e dependências coloniais". A burguesia européia, ele sustentou, poderia sacrificar "todo o excedente no país natal, enquanto continua em posição de obter superlucros nas colônias". Assim, o destino do Ocidente estava sendo determinado no Oriente. Em suas Teses Suplementares ao Congresso, ele suavizou sua afirmação: “O capitalismo europeu obtém a sua força, basicamente, não tanto nos países industrializados da Europa como das suas possessões coloniais”. Selected Works of M.N.Roy, v. 1, 1917-1922, p. 174.

Referências bibliográficas

BROWDER, Robert Paul \& KERENSKY, Alexander F. (eds.). The Russian Provisional Government. 1917. Documents. Stanford, Stanford University Press, 1961.

CARRERE d'ENCAUSSE, Helene. The great challenge: nationalities and the bolshevik State: 1917-1930. Transl. Nancy Festinger. New York, Holmes and Meier, 1991.

GITELMEN, Zvi Y. Jewish nationality and Soviet politics: the Jewish sectios of the CPSU: 1917-1930. Princeton, Princeton University Press, 1972.

KAPPELER, Andreas. Russland als Vielvolkerreich: Entstehung, Geschichte, Zerfall. Munich, C.H. Beck'sche Verlagsbuchhadlung, 1992.

KAZEMZADEH, Firuz. The struggle for Transcancasia: 1917-1921. New York, Philosophical Library, 1951.

MARTIN, Terry D. An affirmative action empire: ethnicity and the soviet State: 19231938. Chicago, 1996. Ph.D. (dissertation) in history. University of Chicago.

PIPES, Richard. The formation of the Soviet Union: communism and mationalism: 1917-1923. Cambridge, Ma, Harvard University Press, 1954.

RAEFF, Marc. Patterns of Russian imperial policy toward nationalities. In: ALLWORTH, Edward (ed.). Soviet nationality problems. New York:, Columbia University Press, 1971.

RADKEY, Oliver H. The agrarian foes of bolshevism: promise and default of the Russian socialist revolutionaries. February to October 1917. New York and London, Columbia University Press, 1958.

ROSENBERG, William G. Liberals and the Russian Revolution: the Constitutional democratic party: 1917-1921. Princeton, Princeton University Press, 1974. 
SLEZKINE, Yuri. Artic mirrors: Russia and the small peoples of the North. Ithaca and London, Cornell University Press, 1994.

SUNY, Ronald Grigor. The revenge of the past: nationalism, revolution and the collapse of the Soviet Union, Stanford, Stanford University Press, 1993.

UPTON, Anthony F. The finnish Revolution: 1917-1918. Minneapolis, University of Minnesota Press, 1980.

ZAIONCHKOVSKII, P.A. Rossiiskoe samoderzhavie v kontse XIX stoletiia. Politicheskaia reaktsiia $80 \mathrm{kh}$ - nachala $90 \mathrm{kh}$ godov. Moscou, Mysl', 1970.

Ronald G. Suny, cientista político, é professor da Universidade de Chicago (EUA).

Parte deste texto foi publicado em Ronald Grigor Suny, The revenge of the past: nationalism, revolution and the collapse of the Soviet Union. Stanford, Stanford University Press, 1993, e será reeditado em Edward Acton \& William R. Rosenberg (eds.). A critical dictionary of the Russian Revolution: 1917-1921.

Tradução de Lenina Pomeranz. O original em inglês - The October Revolution and the nationalities problem - encontra-se à disposição do leitor no IEA-USP para eventual consulta. 